\title{
Fluktuasi Kondisi Megabentos di Perairan Ternate, Maluku Utara
}

\author{
Ucu Yanu Arbi'*, Agustinus Harahap2 dan Hendrik A.W. Cappenberg' \\ 'Pusat Penelitian Oseanografi. Lembaga Ilmu Pengetahuan Indonesia \\ Jl. Pasir Putih I, Ancol Timur, Jakarta Utara, Jakarta 14430 \\ 2Fakultas Perikanan dan IImu Kelautan, Universitas Sam Ratulangi \\ Jl. Kampus Bahu, Manado, Sulawesi Utara 95115 \\ Email: uyanua@gmail.com
}

\section{Abstract \\ Fluctuations in Megabentos Conditions in Ternate waters, North Maluku}

The coral reef was a habitat for several groups of biota that live in this ecosystem. Some species or group species of benthic fauna are known to be ecologically important and others are economically important so that they can be used as indicators to assess reef health. Research on megabenthic fauna in Ternate and its surrounding waters, North Maluku, was carried out in 2012, 2015, 2016, 2017 and 2018 at fourteen permanent stations. The purpose of this study was to determine the fluctuations in several megabenthic faunae temporarily. Data were collected using the modified Belt Transect Method, namely Benthos Belt Transek method. Eight species or groups of megabenthic fauna in the coral reef have been observed. The highest distribution and abundance of megabenthic fauna was coral polyps eating-snail of Drupella spp. The species wealth index decreased from 2012 to 2017 (1.17 to 1.05) but experienced an increase in 2018 (to 1.29). The relatively high dominance found in the megabenthic fauna community was observed in 2015, 2016 and 2017, while in 2012 and 2018 it had relatively low dominance. The megabenthic fauna community observed in 2012 and 2018 has relatively high diversity, whereas in 2015, 2016 and 2017 , the diversity is relatively low. The megabenthic fauna community observed in 2012 and 2018 has spread evenly, while in 2015, 2016 and 2017, the relative prevalence of fauna is relatively uneven.

Keywords: Fluctuations; Megabenthic fauna; Ternate waters

\section{Abstrak}

Terumbu karang merupakan habitat bagi beberapa kelompok biota yang hidup di dalamnya. Beberapa spesies atau kelompok spesies bentos diketahui bernilai ekologis pentingdan yang lainnya bernilai ekonomis penting sehingga dapat dijadikan sebagai indikator untuk menilai kesehatan terumbu. Penelitian fauna megabentos di perairan Ternate dan sekitarnya, Maluku Utara dilakukan pada tahun 2012, 2015, 2016, 2017 dan 2018 pada empat belas stasiun permanen. Tujuan penelitian ini adalah untuk mengetahui fluktuasi beberapa indeks ekologi megabentos dari tahun ke tahun. Pengambilan data menggunakan metode Benthos Belt Transect yang dimodifikasi dari Belt Transect Method. Sebanyak delapan kelompok jenis atau kelompok jenis megabentos pada perairan terumbu karang telah diamati. Sebaran dan kelimpahan megabentos tertinggi adalah siput pemakan polip karang Drupella spp. Indeks kekayaan spesies mengalami penurunan tahun 2012 hingga 2017 (1,17 menjadi 1,05), namun mengalami peningkatan pada tahun 2018 (menjadi 1,29). Dominansi yang relatif tinggi dijumpai pada komunitas megabentos yang teramati pada tahun 2015, 2016 dan 2017, sedangkan pada tahun 2012 dan 2018 memiliki dominansi yang relatif rendah. Komunitas megabentos yang teramati pada tahun 2012 dan 2018 memiliki keanekaragaman yang relatif tinggi, sedangkan pada tahun 2015, 2016 dan 2017 berkeanekaragaman relatif rendah. Komunitas megabentos yang teramati pada tahun 2012 dan 2018 memiliki kemerataan fauna yang relatif merata, sedangkan pada tahun 2015, 2016 dan 2017 memiliki kemerataan fauna yang relatif tidak merata.

Kata Kunci: Fluktuasi; Fauna Megabentos; Perairan Ternate 


\section{PENDAHULUAN}

Propinsi Maluku Utara yang diresmikan pada tanggal 12 Oktober 1999 dibentuk melalui Undang-undang No. 46 Tahun 1999. Sebagai salah satu propinsi kepulauan, Maluku Utara juga dikenal sebagai wilayah yang memiliki sebaran terumbu karang yang cukup luas. Terumbu karang merupakan habitat bagi beberapa biota yang hidup di dalamnya. Ekosistem ini memiliki peran seperti: sebagai tempat ikan-ikan mencari makan, memijah dan berlindung, terumbu karang juga menjaga garis pantai dari ancaman abrasi. Di bidang perikanan, terumbu karang adalah komplek habitat yang menjadi tempat bagi banyak biotabiota laut untuk memijah, membesarkan anakan, mencari makan dan bahkan untuk berlindung sehingga mampu memberikan banyak hasil sumber daya perikanan (baik itu ikan, krustasea, moluska, teripang, dan biota ekonomis penting lainnya) (Moberg \& Folke, 1999). Selain itu, terumbu karang dapat bermanfaat sebagai tempat wisata dan sarana edukasi bawah air, hal ini akan membuka banyak lapangan pekerjaan baru bagi masyarakat sekitar dan akhirnya mampu meningkatkan perekonomian masyarakat pesisir (Brander et al., 2007; McCook et al., 2010). Namun perubahan iklim secara global mengakibatkan perubahan baik dari segi ekologis maupun fungsi fisiknya. Secara fisik kondisi terumbu karang baik tercemin dari tutupan karang hidup. Kondisi ini dapat mengindikasikan perubahan kondisi terumbu karang. Sedangkan dari segi ekologis, menurunnya kelimpahan dan diversitas biota asosiasi, seperti ikan, lobster, udang karang serta moluska ekonomis penting, dapat menjadi indikasi bahwa terumbu karang menurun fungsi ekologisnya yaitu dalam menyediakan habitat yang baik untuk hewan-hewan tersebut.

Terumbu karang di wilayah perairan Ternate dan sekitarnya merupakan tipe karang tepi (fringing reef) yang terletak di tepi pulau. Karakteristik dari karang tepi di daerah ini umumnya mempunyai slope yang tidak terlalu curam, dimana karang masih dapat dijumpai hingga kedalaman sekitar 20 - 30 meter. Terumbu karang berada di lokasi yang dekat dengan aktivitas penduduk dan juga berdekatan dengan dengan muara sungai, terutama yang berada di Pulau Ternate. Tutupan karang hidup atau life coral (LC) di wilayah ini berada dalam kisaran $32.54 \pm 4 \%$ dan berarti masuk dalam kategori sedang (Giyanto et al., 2017). Tutupan karang ini relatif seimbang dengan tutupan karang mati yang tertutup alga atau dead coral algae (DCA) yang berkisar $30.05 \pm 1.7 \%$. Kondisi ini menandakan bahwa karang masih mempunyai ruang untuk tumbuh yang luas sehingga kondisi terumbu karang dapat meningkat ke kategori baik apabila didukung kondisi perairan yang sesuai. Meskipun demikian ketegori benthik yang lain juga perlu mendapat perhatian karena merupakan kompetitor karang seperti karang lunak atau soft corals (SC) dan spons atau sponges (SP).

Beberapa spesies atau kelompok
spesies bentos telah diketahui dapa
dijadikan sebagai indikator untuk menila
kesehatan terumbu (bernilai ekologis
penting), dan beberapa spesies atau kelompok spesies lainnya sejak lama dikenal sebagai target tangkapan nelayan (bernilai ekonomis penting). Kelompok fauna yang hidup di dasar substrat atau fauna bentik yaitu Krustasea, Moluska, Ekinodermata dan Polychaeta merupakan penyusun ekosistem terumbu karang yang cukup dominan di ekosistem tersebut. Kelompok tersebut sebagian memiliki ukuran yang relatif besar (megabentos) sehingga dapat dengan mudah dijumpai dan memiliki jumlah jenis serta jumlah individu yang cukup banyak. Kelompok fauna bentik juga memiliki peranan penting terhadap kondisi dan kestabilan ekosistem. Pentingnya peranan kelompok fauna bentik menjadikannya potensial sebagai objek untuk monitoring kesehatan terumbu karang.

Data hasil penelitian megabentos di lokasi ini masih belum banyak, terlebih yang dikaitkan dengan kondisi terumbu karang. Sehingga sasaran dari penelitian ini adalah tersedianya data pemantauan megabentos di Perairan Ternate dan sekitarnya secara periodik untuk mendapatkan gambaran kondisi megabentos pada periode waktu tersebut. Lebih jauh lagi, tujuan dari penelitian ini adalah untuk mengetahui 
fluktuasi beberapa indeks ekologi megabentos di perairan Ternate dan sekitarnya dari tahun ke tahun.

\section{MATERI DAN METODE}

Penelitian dilakukan di daerah pesisir perairan kepulauan Ternate dan sekitarnya, Provinsi Maluku Utara, termasuk didalamnya pulau-pulau di sekitarnya seperti Pulau Ternate, Pulau Tidore, Pulau Hiri, Pulau Maitara, Pulau Failonga dan Teluk Sofifi di
Halmahera Barat. Pengamatan dilakukan pada 14 stasiun yakni: 4 stasiun di Pulau Ternate (Desa Sulamadaha, Desa Tabam, Pusat Kota Ternate dan Desa Sasa), 1 stasiun di Pulau Hiri bagian selatan (Desa Dorari Isa), 3 stasiun di Pulau Tidore (Desa Akebai dan Desa Pasimayou), 1 stasiun di Pulau Failonga dan 3 stasiun di Halmahera Barat dan sekitarnya (bagian barat daya Pulau Dehe di Desa Sidangoli, Pulau Dodinga dan Pulau Sibu). Lokasi dan posisi koordinat masingmasing stasiun (Gambar 1 dan Tabel 1).

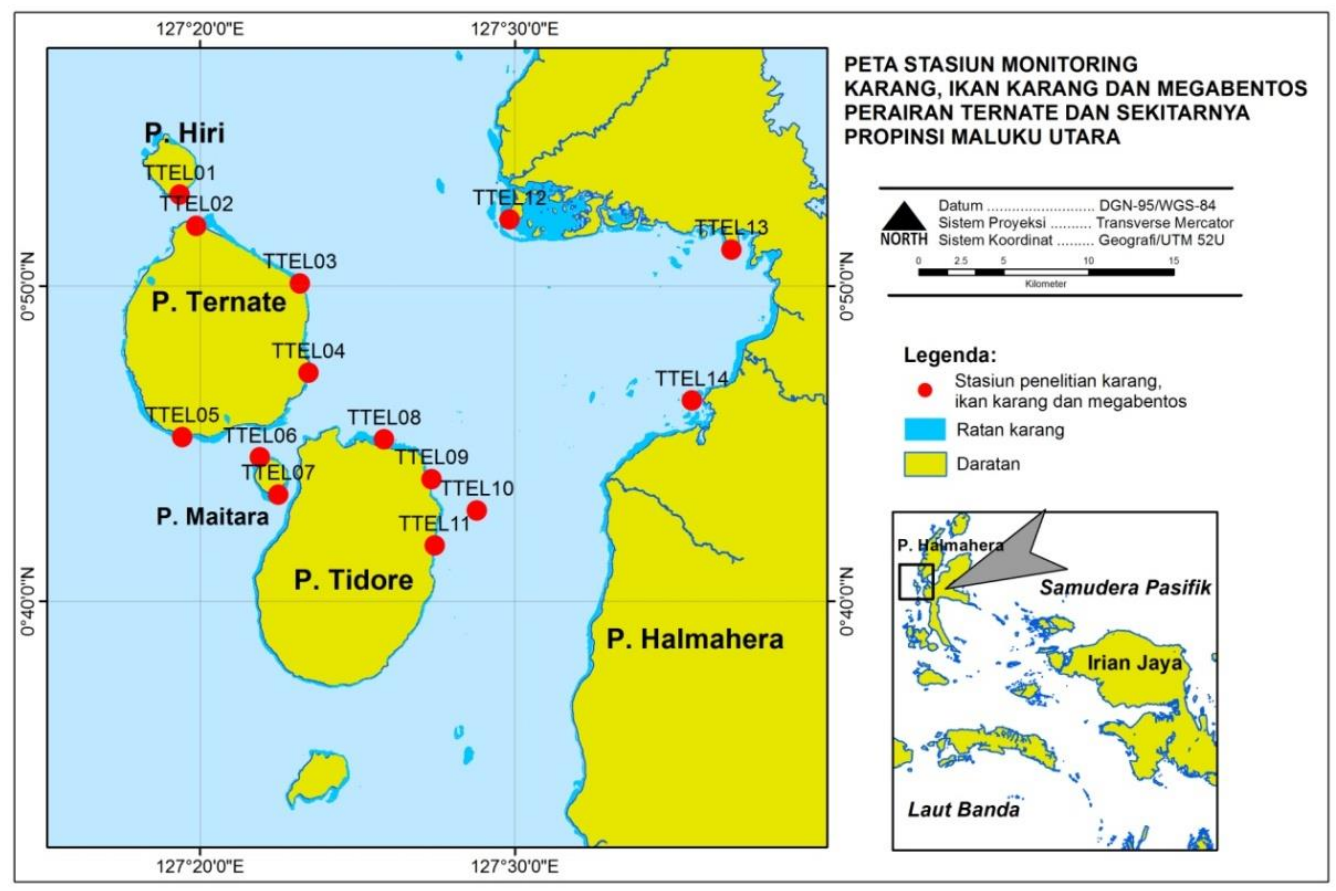

Gambar 1. Peta stasiun penelitian megabentos di perairan Ternate dan sekitarnya

Tabel 1. Lokasi stasiun penelitian megabentos di perairan Ternate dan sekitarnya

\begin{tabular}{lcccl}
\hline \multicolumn{1}{c}{ Lokasi } & Stasiun & BT & LU & \\
\hline \multirow{5}{*}{ Ternate } & TTEC01 & $127,32267 \circ$ & $0,88144 \circ$ & Pulau Hiri \\
& TTEC02 & $127,33150^{\circ}$ & $0,86494^{\circ}$ & Pulau Ternate (bagian utara) \\
& TTEC03 & $127,38635^{\circ}$ & $0,83451^{\circ}$ & Pulau Ternate (bagian timur laut) \\
& TTEC04 & $127,39080^{\circ}$ & $0,78717^{\circ}$ & Pulau Ternate (bagian timur) \\
& TTEC05 & $127,32404^{\circ}$ & $0,75325^{\circ}$ & Pulau Ternate (bagian selatan) \\
Tidore & TTEC06 & $127,36523^{\circ}$ & $0,74245^{\circ}$ & Pulau Maitara (bagian utara) \\
Kepulauan & TTEC07 & $127,37496^{\circ}$ & $0,72276^{\circ}$ & Pulau Maitara (bagian selatan) \\
& TTEC08 & $127,43081^{\circ}$ & $0,75204 \circ$ & Pulau Tidore (bagian utara) \\
& TTEC09 & $127,45589 \circ$ & $0,73095^{\circ}$ & Pulau Tidore (bagian timur laut) \\
Halmahera & TTEC10 & $127,47985^{\circ}$ & $0,71444^{\circ}$ & Pulau Tidore (bagian timur laut) \\
Barat & TTEC11 & $127,45757^{\circ}$ & $0,69584^{\circ}$ & Pulau Tidore (bagian timur) \\
& TTEC12 & $127,49722^{\circ}$ & $0,86831^{\circ}$ & Pulau Halmahera(Desa Sidangoli) \\
& TTEC13 & $127,61461^{\circ}$ & $0,85239 \circ$ & Pulau Halmahera(Desa Dodinga) \\
\hline
\end{tabular}


Pengamatan megabentos dilakukan dengan menggunakan metode Benthos Belt Transect yang merupakan pengembangan dari Belt Transect Method dengan bantuan peralatan selam SCUBA (Loya, 1978). Metode ini dilakukan dengan cara menarik garis sejajar garis pantai pada kedalaman 5 - 10 meter sepanjang 70 meter dan lebar pengamatan satu meter ke arah kiri kanan garis transek. Sehingga luas area pengamatan megabentos adalah $70 \times 2=$ $140 \mathrm{~m}^{2}$ (Gambar 2). Semua jenis megabentos yang ditemukan dalam transek dicatat nama spesies atau kelompok spesiesnya serta jumlah individunya, terutama spesies dan kelompok spesies megabentos yang menjadi target penelitian. Megabentos yang dipilih sebagai target penelitian merupakan biota yang memiliki kriteria sebagai biota yang bernilai ekonomis dan nilai ekologis penting yang keberadaannya sangat berkaitan erat dengan kondisi kesehatan karang (Arbi \& Sihaloho, 2017). Megabentos target monitoring terdiri dari delapan spesies atau kelompok spesies seperti yang disajikan pada Tabel 2. Identifikasi terhadap spesies dan kelompok spesies merujuk pada Abbott dan
Dance (1990), Matsura et al. (2000), Clark dan Rowe (1971), Neira dan Cantera (2005) dan Colin dan Arneson (1995).

Analisis dilakukan dengan menelaah kehadiran jenis atau kelompok jenis megabentos beserta jumlahnya, distribusi pada setiap stasiun, kepadatan setiap stasiun dan kepadatan setiap jenis atau kelompok jenis megabentos. Indeks-indeks ekologis seperti indeks dominansi Simpson (D), indeks keanekaragaman jenis Shannon-Wiener $\left(H^{\prime}\right)$, indeks kemerataan Pielou (J') dan indeks kekayaan jenis Margalef (d) selanjutnya dihitung untuk menelaah keanekaragaman fauna megabentos. Dalam analisis data fluktuasi tahun 2012-2018, data jumlah individu setiap tahun diuji normalitas distribusi dengan uji Shapiro Wilk, homogenitas varians dengan uji Levene, untuk kemudian ditelaah dengan uji Kruskal-Wallis. Bila ditemukan perbedaan yang bermakna, analisis ditindak lanjuti dengan Uji Nemenyi. Pembandingan pengamatan terakhir (2018) dengan tahun sebelumnya (2017) dilakukan dengan uji Student-t berpasangan.

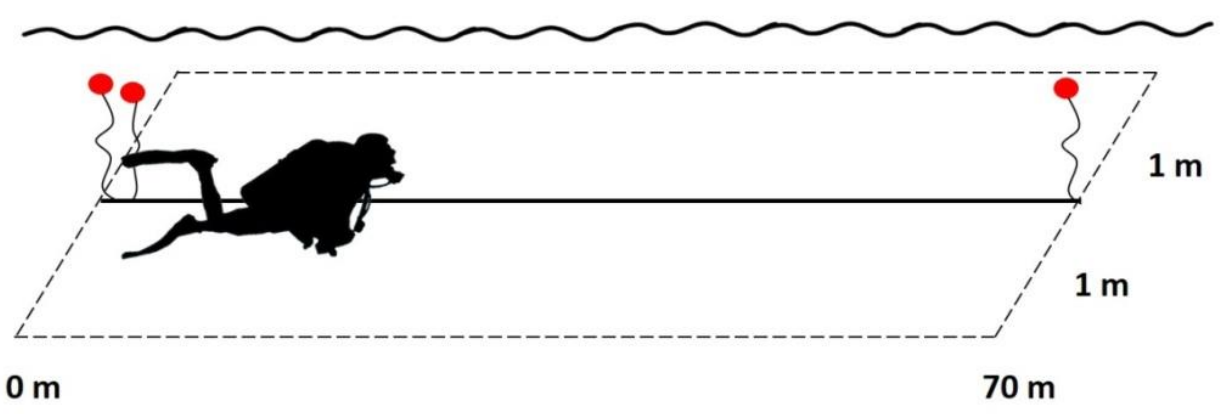

Gambar 2. Skema transek pengamatan megabentos dengan metode Benthos Belt Transect yang dimodifikasikan dari Belt Transect Method

Tabel 2. Spesies atau kelompok spesies megabentos target penelitian

\begin{tabular}{lll}
\hline \multicolumn{1}{c}{ Megabentos Target } & Nama Spesies / Kelompok Spesies & \multicolumn{1}{c}{ Group } \\
\hline Bintang Laut Berduri & Acanthaster planci & Echinodermata \\
Bulu Babi & Echinoidea & Echinodermata \\
Teripang & Holothuroidea & Echinodermata \\
Bintang Laut Biru & Linckia laevigata & Echinodermata \\
Kerang Kima & Tridacna spp., Hippopus spp. & Mollusca \\
Siput Drupella & Drupella spp. & Mollusca \\
Keong Lola & Trochus spp., Tectus spp. & Mollusca \\
Lobster & Paniluridae & Crustacea \\
\hline
\end{tabular}




\section{HASIL DAN PEMBAHASAN}

Di beberapa lokasi, seperti yang terlihat pada Stasiun TTECO1 dan TTECO2, tutupan spons dan karang lunak cukup tinggi.Secara lengkap, persentase tutupan untuk masing-masing kategori benthik di tampilkan pada Gambar 3.

Pemahaman tentang struktur komunitas fauna berada pada habitat tertentu biasanya dilakukan berdasarkan penelaahan keanekaragaman melalui perhitungan beberapa indeks ekologis yang umum digunakan.Selain itu, penggunaan indeks ekologis dapat pula digunakan untuk perbandingan temporal atau monitoring untuk lokasi yang sama. Keanekaragaman fauna megabentos di perairan Ternate, Tidore dan barat Halmahera pada tahun 2018 ini dikaji melalui beberapa indeks seperti indeks kekayaan jenis Margalef (IMarg), yang dapat dilihat pada Gambar 4,dan indeks dominansi Simpson (D), indeks keanekaragaman Shannon-Wiener $\left(\mathrm{H}^{\prime}\right)$, dan indeks kemerataan Pielou (J') yang dapat dilihat pada Gambar 5.

Kondisi perairan umumnya diasumsikan baik dan stabil bila nilai indeks dominansi rendah, indeks keanekaragaman tinggi, indeks kemerataan jenis tinggi dan indeks kekayaan spesies tinggi.Hal yang penting untuk diingat dalam interpretasi nilai indeksindeks ini adalah bahwa jenis-jenis yang diamati terbatasi pada 8 jenis atau kelompok jenis fauna megabentos yang sebelumnya telah ditentukan (finite population).

Ukuran kekayaan jenis yang paling sederhana adalah jumlah jenis. Ukuran kekayaan jenis berikutnya yang juga kerap digunakan adalah indeks kekayaan jenis Margalef (lMarg) yang menyertakan jumlah individu dalam perhitungan. Nilai indeks kekayaan spesies (IMarg) pada masing-masing stasiun berkisar antara $0-2,23$ (Gambar 4). Kekayaan jenis fauna megabentos yang berbeda-beda pada setiap sasiun dipengaruhi oleh kondisi habitat tempat hidup. Habitat yang kompleks memberi pilihan habitat (lubang, liang, celah) yang lebih banyak, ruang hidup atau luas permukaan yang lebih banyak, tempat berlindung (refugia) yang lebih banyak dan lebih mampu mendukung kehidupan fauna yang lebih melimpah dan beragam sebagai akibat makin banyaknya habitat potensial (Entrambasaguas et al., 2008). Khusus untuk jenis-jenis fauna megabentos yang memiliki nilai ekonomis penting, keberadaan di alam saat pengamatan bisa juga telah dipengaruhi oleh aktivitas eksploitasi pemanfaatan oleh manusia.

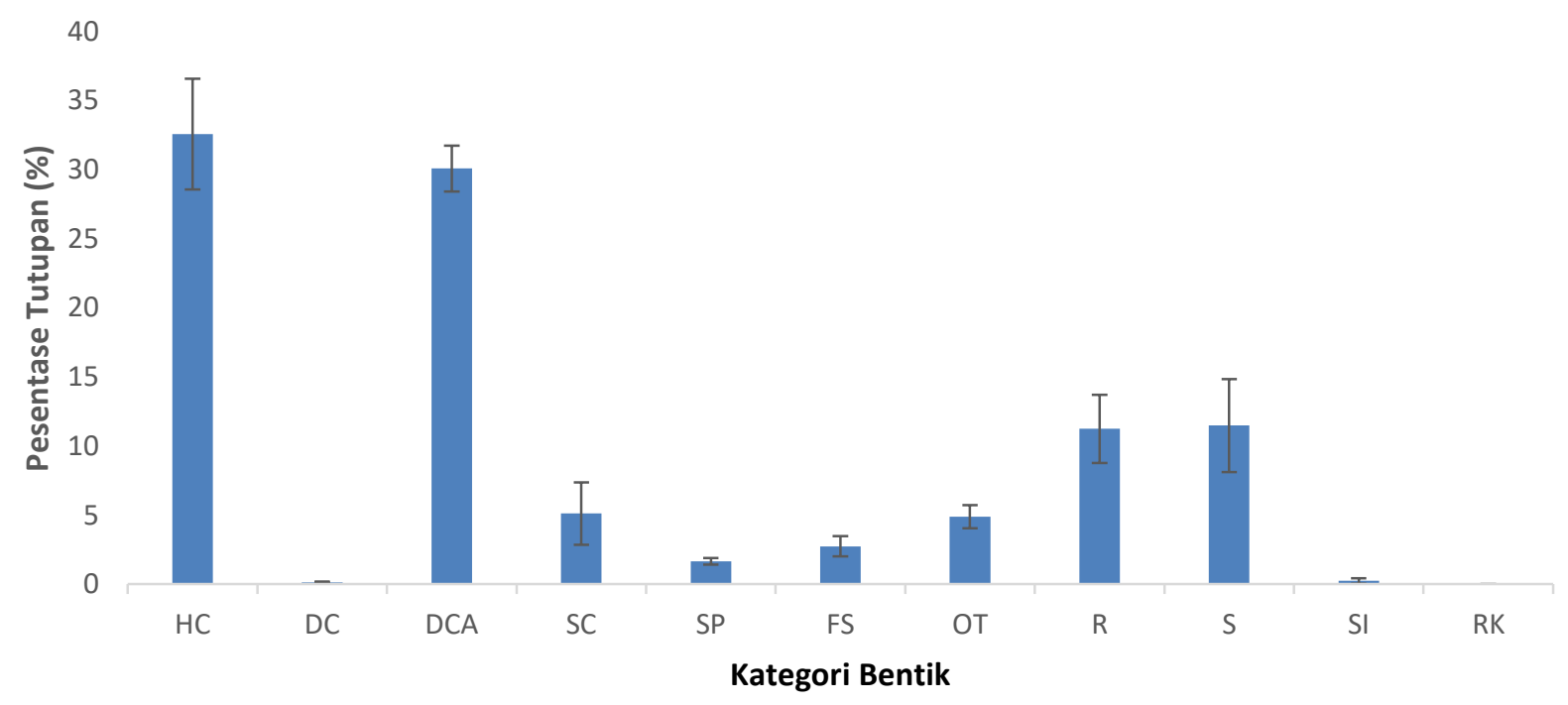

Gambar 3. Persentase tutupan karang untuk masing-masing kategori bentik (HC: hard coral, DC: dead coral, DCA: dead coral with algae, SC: soft coral, SP: spons, FS: fleshy seaweed, OT: others, R: rubble, S: sand, Si: silt, RK: Rock) 


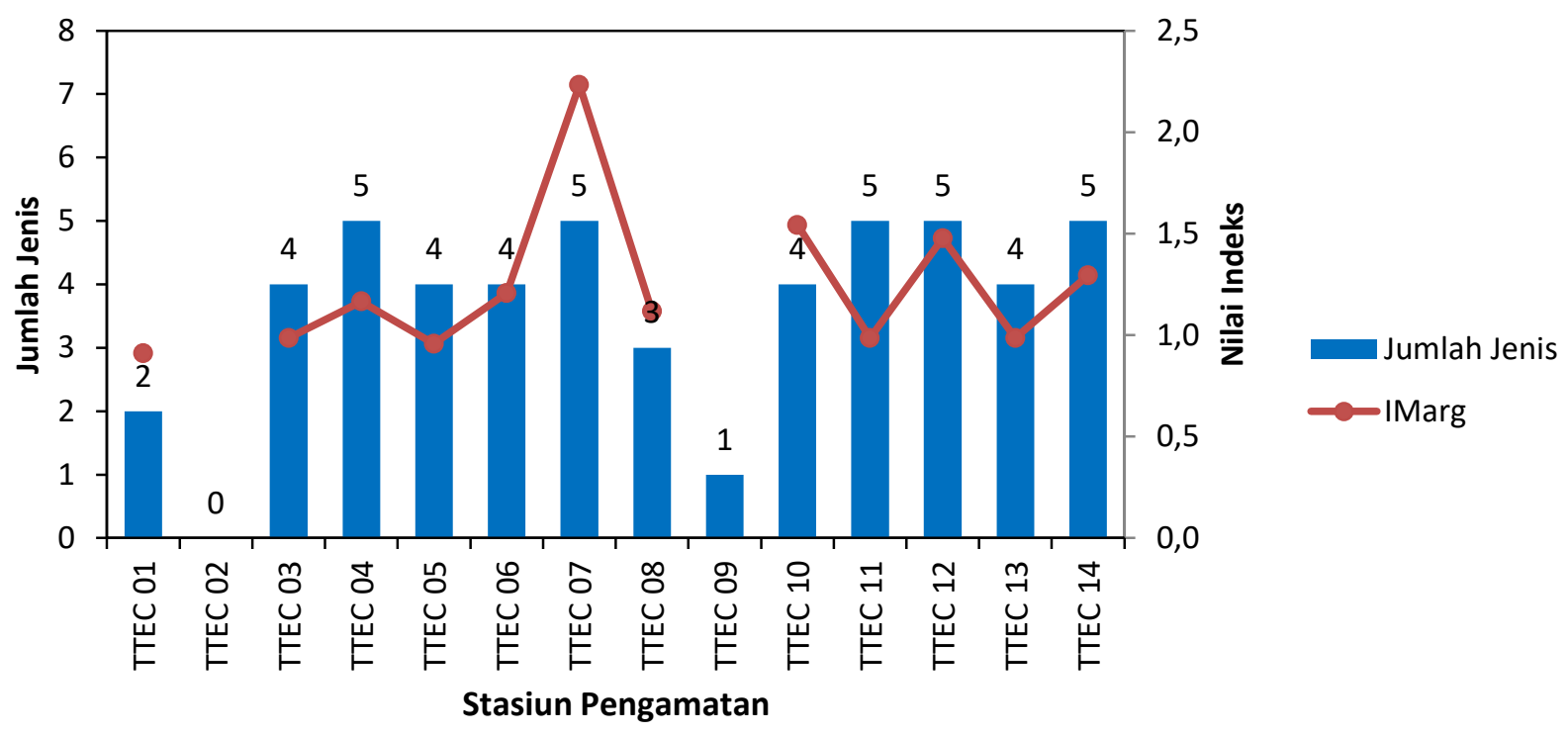

Gambar 4. Indeks Kekayaan Jenis Margalef (lMarg) megabentos di perairan Ternate dan sekitarnya tahun 2108

Nilai indeks dominansi ditentukan oleh proporsi jumlah individu masing-masing jenis yang dijumpai di suatu lokasi yang sama. Bila proporsinya berimbang, nilai dominansi akan rendah, demikian pula sebaliknya. Nilai indeks ini berkisar dari 0-1,0 yang menyatakan dominansi rendah hingga tinggi. Nilai indeks dominansi (D) berkisar antara 0,22 - 1,0 (Gambar 5). Dengan menggunakan nilai indeks dominansi 0,5 sebagai acuan adanya dominansi, maka dapat dikatakan bahwa dominansi dijumpai pada 6 stasiun yaitu Stasiun TTECO1 (oleh bintang laut biru Linckia laevigata), Stasiun TTEC03 (oleh siput pemakan polip karang Drupella spp.), Stasiun TTEC05 (oleh siput pemakan polip karang Drupella spp.), Stasiun TTEC09 (oleh bulu babi), Stasiun TTEC11 (oleh siput pemakan polip karang Drupella spp.) dan Stasiun TTEC13 (oleh bintang laut biru Linckia laevigata).

Indeks keanekaragaman menyatakan diversitas jenis pada setiap stasiun, dimana biasanya berbanding terbalik dengan indeks dominansi. Semakin tinggi dominansi, semakin rendah keanekaraman dan demikian pula sebaliknya. Indeks ini bernilai dari 0-H'Max (yang merupakan Ln dari jumlah jenis maksimum, yang dalam hal ini adalah 8 jenis atau kelompok jenis, hingga $H^{\prime}$ Max adalah 2,08. Indeks keanekaragaman yang teramati di perairan Pulau Ternate,
Pulau Tidore dan barat Pulau Halmahera berkisar antara $0-1,56$ (Gambar 5). Karena populasi terbatasi pada 8 jenis atau kelompok jenis saja, maka nilai maksimum indeks keanekaragaman ' $\mathrm{H}^{\prime}$ ini adalah 2,08. Bila digunakan asumsi bahwa indeks keanekaragaman yang lebih besar dari $50 \%$ nilai tersebut (atau 1,04) adalah berkeanekaragaman tinggi, maka dapat dikatakan bahwa enam stasiun (Stasiun TTEC04, Stasiun TTEC06, Stasiun TTEC07, Stasiun TTEC 10, Stasiun TTEC 12, dan Stasiun TTEC 14) memiliki keanekaragaman yang relatif tinggi, sedangkan stasiun-stasiun lainnya berkeanekaragaman rendah.

$$
\text { Indeks kemerataan Pielou }
$$
menggambarkan kestabilan suatu komunitas perairan berdasarkan kemerataan jumlah individu jenis fauna yang hidup pada suatu lokasi. Suatu komunitas dikatakan stabil bila tersusun dari jenis-jenis dengan jumlah individu yang merata. Nilai indeks kemerataan jenis akan mendekati nilai 1 bila jumlah individu merata dan sebaliknya akan mendekati nilai 0 bila jumlah individu tidak merata. Karena penyebaran jumlah individu yang tidak merata juga mengindikasikan adanya dominasi oleh jenis tertentu, maka indeks kemerataan ini biasanya berbanding terbalik dengan indeks dominansi. Nilai indeks kemerataan yang dijumpai berkisar antara 00,97 (Gambar 5). Nilai indeks kemerataan 
$\leq 0,5$ menunjukkan ada beberapa jenis fauna yang lebih dominan dibanding jenis yang lain. Dengan demikian, sebagian besar stasiun pengamatan (10 stasiun) menunjukkan kemerataan fauna megabentos yang relatif merata, kecuali 4 stasiun sisanya, yaitu Stasiun TTECO2 (tidak dijumpai megabentos), Stasiun TTEC03 (didominasi oleh siput pemakan polip karang Drupella spp.), Stasiun TTEC09 (hanya dijumpai 1 jenis saja) dan Stasiun TTEC11 (didominasi oleh siput pemakan polip karang Drupella spp.).

Secara keseluruhan, indeks-indeks keanekaragaman di perairan Pulau Ternate, Pulau Tidore dan barat Pulau Halmahera dapat dilihat pada Tabel 3. Secara keseluruhan keanekaragaman megabentos di perairan tersebut memiliki dominansi yang relatif rendah $(<0,5)$, keanekaragaman yang relatif tinggi (melebihi $50 \%$ dari nilai maksimum) dan kehadiran jenis yang relatif cukup merata.

Sebagai pembanding, penelitian tentang keanekaragaman perairan Pulau
Moti, suatu pulau lain di sebelah utara lokasi penelitian memperoleh Indeks Kekayaan Jenis 1,18-1,22, Indeks Keanekaragaman ( $\left.\mathrm{H}^{\prime}\right)$ $1,05-1,20$ dan Indeks Kemerataan (J') 0,950,99 (Yusron, 2006). Sekalipun penelitian tersebut hanya dikhususkan pada satu kelompok Echinodermata, pembandingan keanekaragaman menunjukkan bahwa perairan dalam penelitian di perairan Pulau Ternate dan sekitarnya ini menunjukkan indeks kekayaan jenis yang relatif lebih tinggi, indeks keanekaragaman yang relatif lebih tinggi, dan indeks kemerataan yang relatif lebih rendah dibanding di perairan Pulau Moti tersebut.

Secara umum, jumlah jenis pada setiap stasiun mengalami fluktuasi selama kurun waktu tersebut (Gambar 6). Menurut tahun pengamatan, rata-rata jumlah jenis megabentos per stasiun adalah 3,6 jenis (2012), 4,4 jenis (2015), 3,2 jenis (2016), 4,9 jenis (2017), dan 3,6 jenis per stasiun pada tahun 2018. Kekayaan jenis atau kehadiran jumlah jenis megabentos yang dijumpai pada setiap stasiun selama kurun waktu 2012-2018 disajikan pada Gambar 7.

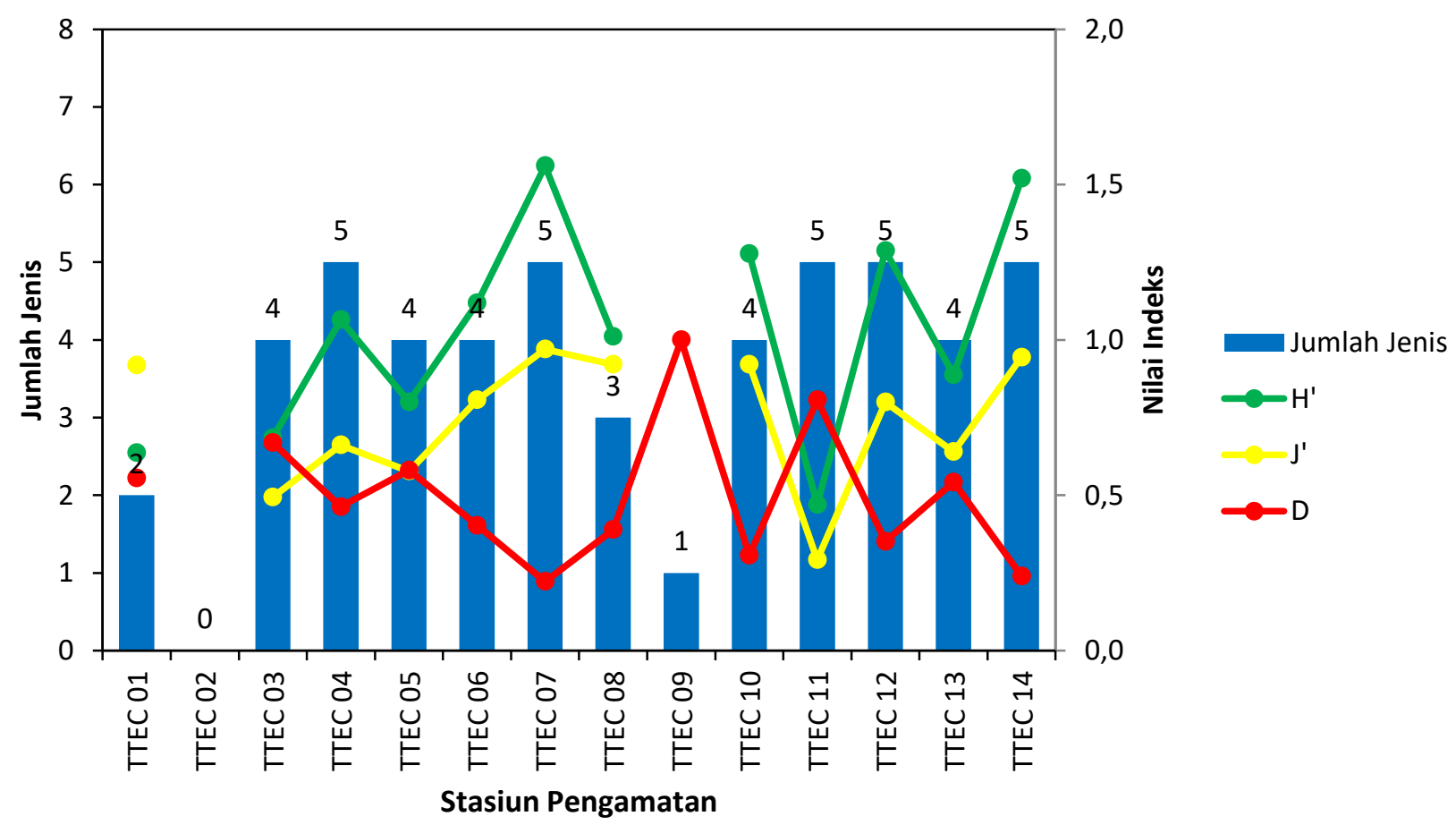

Gambar 5. Indeks Dominansi (D), Keanekaragaman (H') dan Kemerataan (J') megabentos di perairan Ternate dan sekitarnya tahun 2018 
Tabel 3. Indeks ekologis megabentos di perairan Ternate dan sekitarnya tahun 2018

\begin{tabular}{lllll}
\hline Karakteristik & Indeks Ekologis & Satuan & Nilai & Kisaran \\
\hline Kekayaan & Kekayaan Spesies Margalef & IMarg & 1,29 & \\
Dominansi & Dominansi Simpson & $\mathrm{D}$ & 0,34 & $0-1$ \\
Diversitas & Keanekaragaman Shannon-Wiener & $\mathrm{H}^{\prime}$ & 1,43 & $0-2,08$ \\
Kemerataan & Kemerataan Pielou & $\mathrm{J}^{\prime}$ & 0,69 & $0-1$ \\
\hline
\end{tabular}

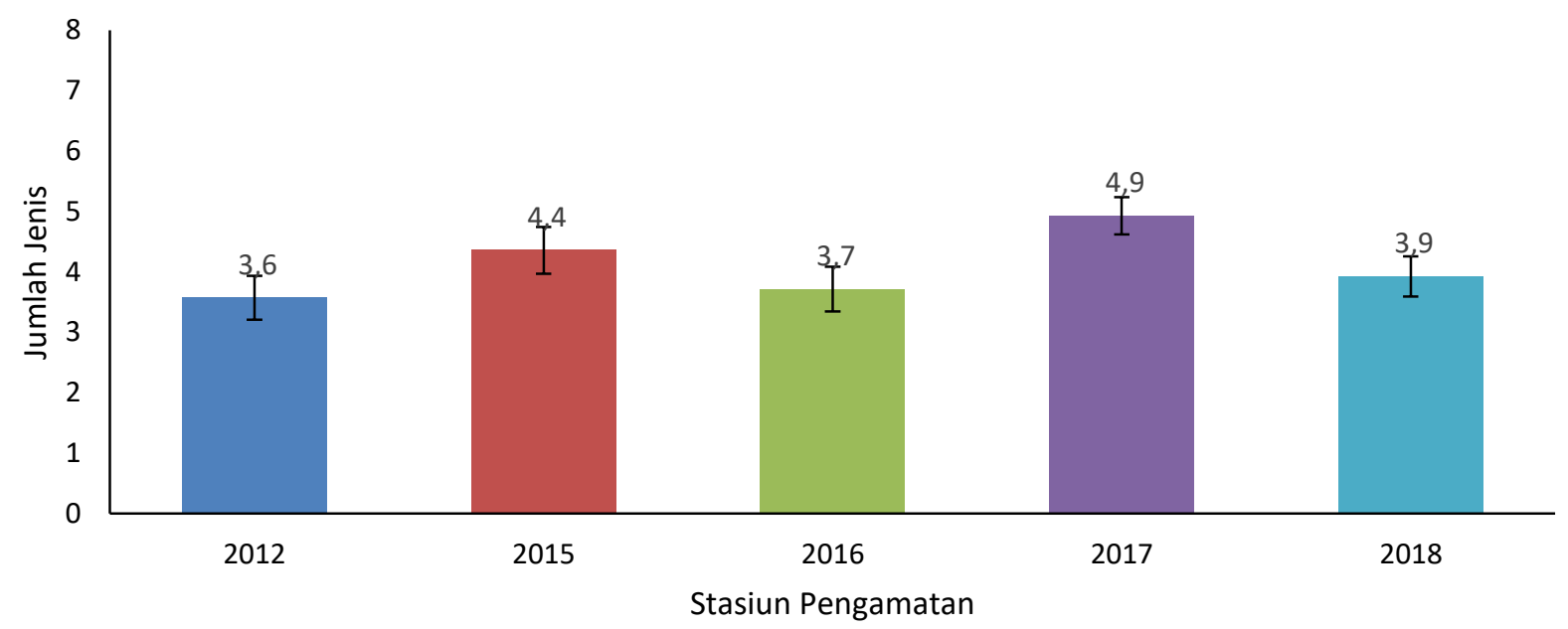

Gambar 6. Rata-rata jumlah jenis atau kelompok jenis megabentos per stasiun di perairan Ternate dan sekitarnya tahun 2012-2018

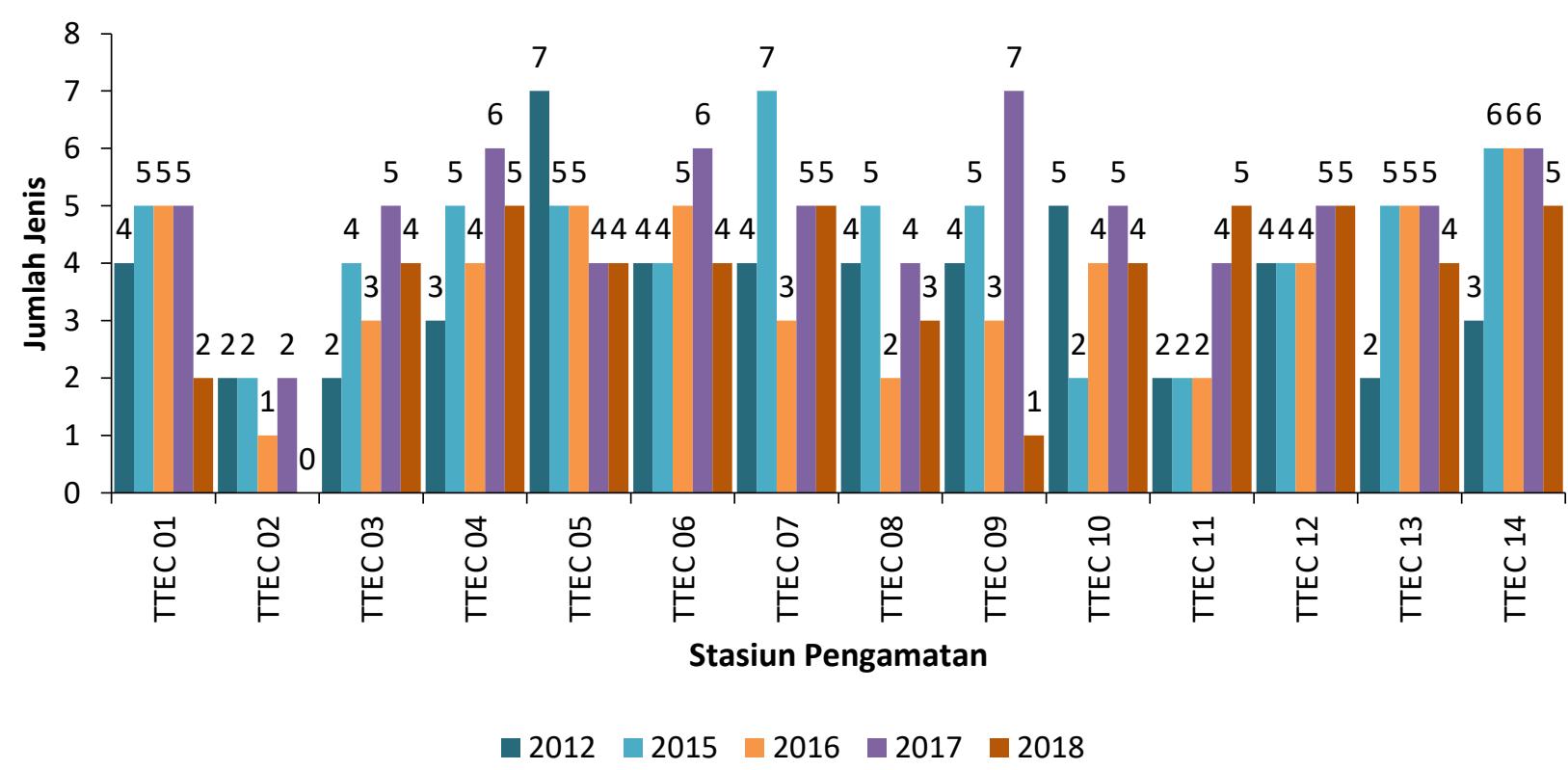

Gambar 71. Jumlah jenis atau kelompok jenis megabentos pada setiap stasiun pengamatan di perairan Ternate dan sekitarnya tahun $2012-2018$

Dari delapan jenis atau kelompok jenis megabentos target, paling banyak hanya 7 jenis atau kelompok jenis yang dijumpai sekaligus pada satu stasiun. Jumlah jenis 
megabentospada setiap stasiun berkisar $0-7$ jenis selama kurun waktu tersebut. Jumlah jenis terbanyak tersebut hanya dijumpai satu stasiun yang berbeda setiap tahun pengamatan, yaitu pada Stasiun TTEC05 (pengamatan tahun 2012), Stasiun TTEC07 (tahun 2015), dan Stasiun TTEC09 (tahun 2017). Rata-rata jumlah jenis dan kisaran jumlah jenis selama kurun waktu 2012-2018 disajikan pada Gambar 8.

Ketersebaran atau kehadiranmasingmasing jenis fauna megabentos, yang dinyatakan dengan jumlah stasiun pengamatan di mana jenis megabentos tersebut dijumpai, dapat dilihat pada Gambar 9.

Selama kurun waktu 2012-2018, ketersebaran bintang laut bermahkota duri Acanthaster planci berkisar antara $1-5$ stasiun dengan rata-rata 2,4 stasiun. Perkembangan terakhir menunjukkan ketersebaran $A$. planci yang meningkat dari 2 stasiun pada tahun 2017 menjadi 5 stasiun pada tahun 2018. Ketersebaran bintang laut biru Linckia laevigata berkisar antara 7-11 stasiun, dengan rata-rata 8,8 stasiun, dengan catatan pada tahun 2012 tidak dilakukan pengamatan. Perkembangan terakhir

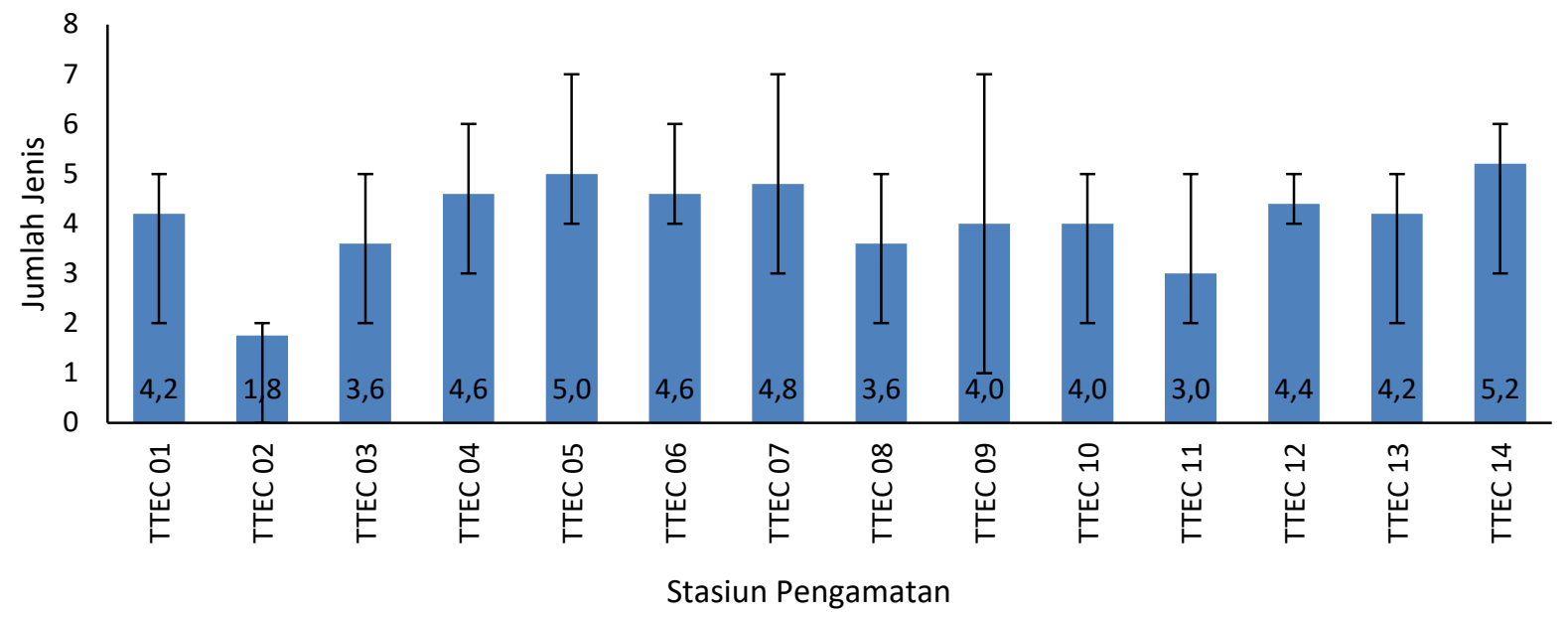

Gambar 8. Rata-rata jumlah jenis atau kelompok jenis megabentos dan kisaran setiap stasiun di perairan Ternate dan sekitarnya tahun $2012-2018$

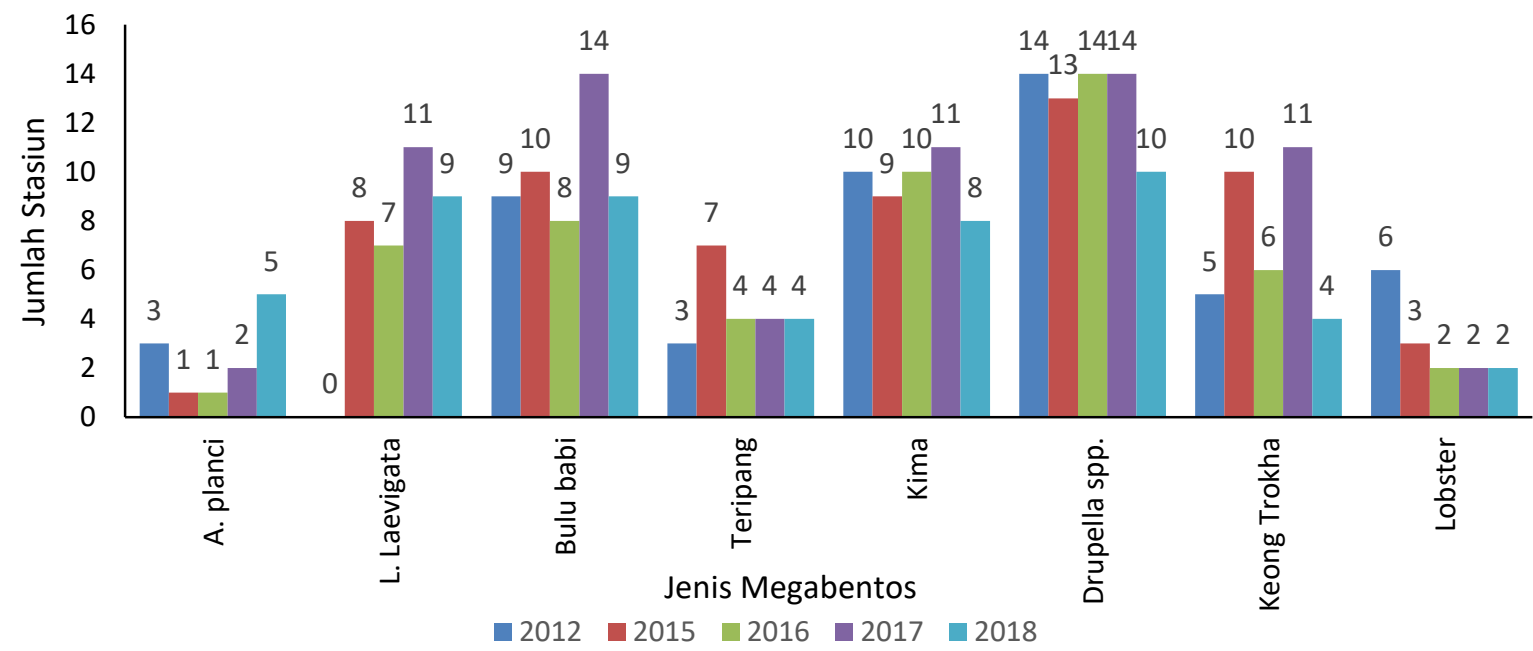

Gambar 9. Ketersebaran setiap jenis atau kelompok jenis megabentos pada masing-masing stasiun di perairan Ternate dan sekitarnya tahun 2012 - 2018 
menunjukkan adanya penurunan ketersebaran dari 11 stasiun (2017) menjadi 9 stasiun saja (2018). Ketersebaran bulu babi berkisar antara 8-14 stasiun, dengan ratarata 10 stasiun. Ketersebaran teripang berkisar antara 3-7stasiun, dengan rata-rata 4,4 stasiun. Ketersebaran kerang kima berkisar antara 8-11 stasiun, dengan rata-rata 9,6 stasiun. Perkembangan terakhir menunjukkan adanya penurunan ketersebaran dari ditemui pada 11 stasiun (2017) menjadi pada 8 stasiun saja pada tahun 2018. Ketersebaran siput pemakan polip karang Drupella spp., yang merupakan megabentos dengan ketersebaran terluas, yaitu berkisar antara 1014 stasiun, dengan rata-rata 13 stasiun. Ketersebaran keong trokha berkisar antara 411 stasiun, dengan rata-rata 7,2 stasiun. Ketersebaran lobster berkisar antara 2-6 stasiun, dengan rata-rata 3 stasiun.

Fluktuasi kepadatan rata-rata (jumlah Ind/ha) pada pengamatan tahun 2012, 2015, 2016, 2017 dan tahun 2018 disajikan pada Gambar 10. Karena siput pemakan polip karang Drupella spp. sangat dominan (mencapai $54-74 \%$ ) dan sangat fluktuatif sehingga sangat mempengaruhi kepadatan keseluruhan, maka jenis ini dibahas terpisah. Kepadatan keseluruhan mengalami peningkatan dari 2012 hingga 2017. Pada tahun 2018 terjadi penurunan sebanyak $72 \%$ dari 4112,2 Ind/hapada tahun 2017 menjadi 1158,2 Ind/ha pada tahun 2017. Namun demikian, uji statistik terhadap kepadatan setiap tahun selama kurun waktu tersebut tidak menunjukkan adanya perbedaan yang bermakna (Kruskal-Wallis, $p=0,89$ ). Penurunan ini sebagian besar karena kontribusi penurunan kepadatan siput pemakan polip karang Drupella spp. pada tahun 2018, yang menurun sebanyak $79 \%$ dari jumlah individu pada tahun 2017. Kepadatan fauna megabentos lainnya berkisar pada 530,6$1.066,3 \mathrm{Ind} / \mathrm{ha}$. Pada tahun 2018, terjadi penurunan kepadatan megabentos lainnya sebanyak $50 \%$ dari kepadatan tahun sebelumnya.

Kepadatan rata-rata setiap stasiun berdasarkan pengamatan periode 20122018 disajikan pada Gambar 11. Fluktuasi kepadatan megabethos pada masingmasing stasiun yang lebih terinci setiap tahunnya selama 2012-2018 (Gambar 12). Kepadatan rata-rata setiap jenis megabentos gabungan selama kurun waktu 2012-2018 dapat dilihat pada

Gambar13, sedangkan fluktuasi kepadatan masing-masing jenis megabentos setiap tahunnya selama (2012-2018) (Gambarl4).

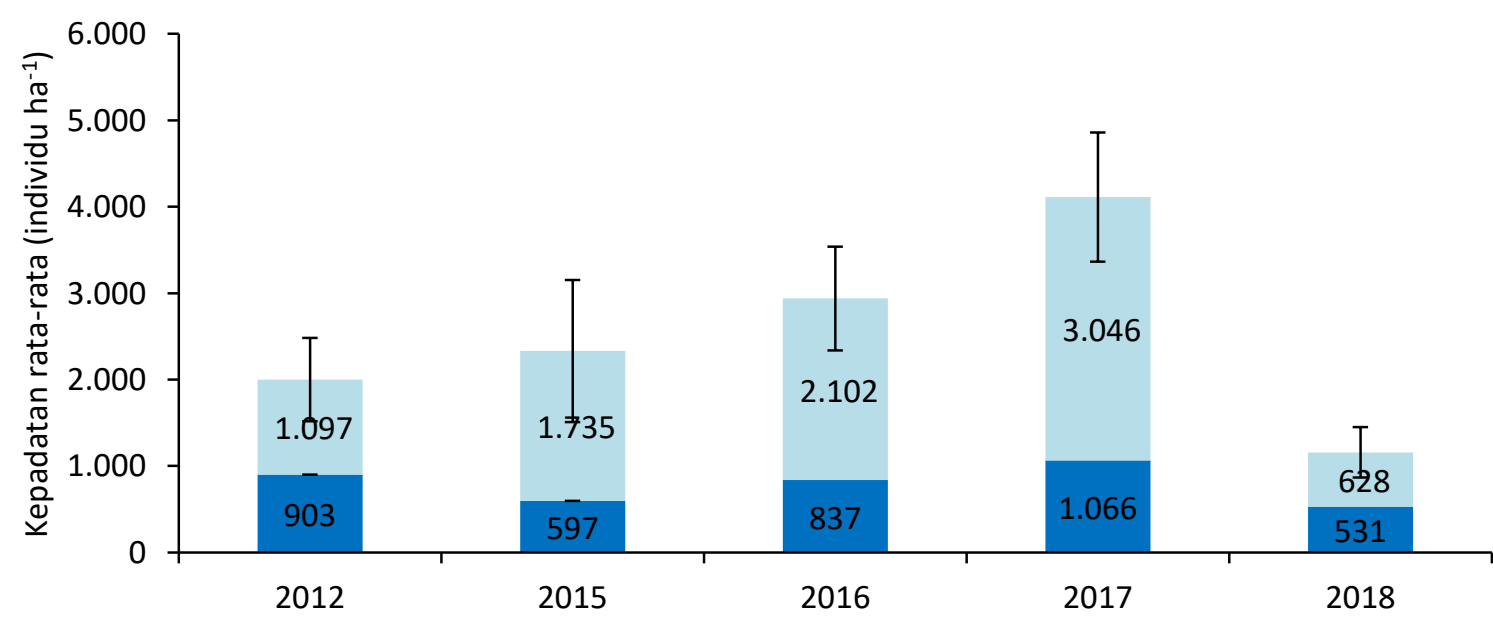

Tahun Pengamatan

- Megabentos lainnya Drupella

Gambar 10. Kepadatan rata-rata (ind/ha) keseluruhan megabentos di perairan Ternate dan sekitarnya pada tahun 2012-2018 


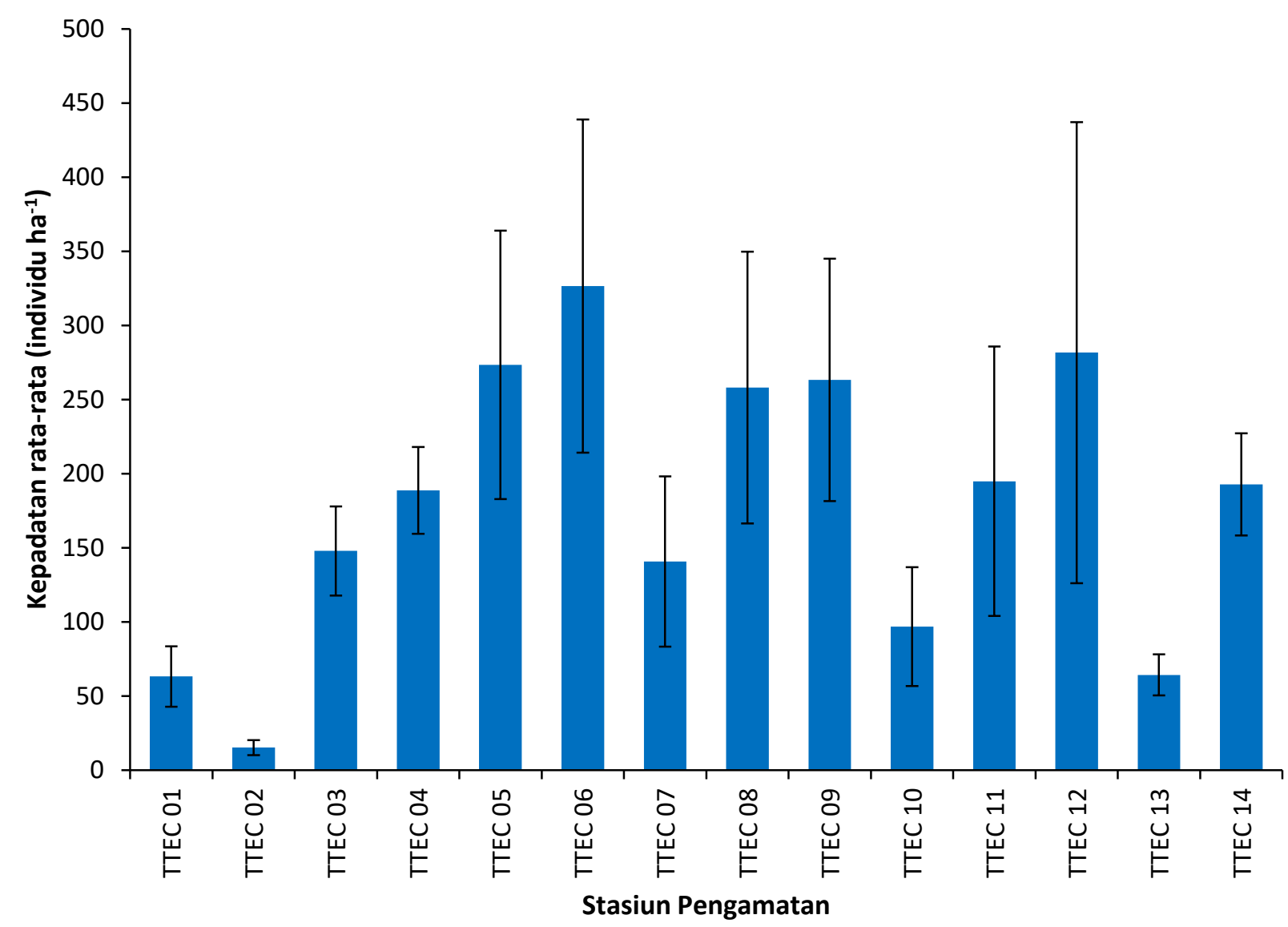

Gambar 11. Kepadatan rata-rata megabentos di perairan Ternate dan sekitarnya setiap stasiun tahun 2012-2018

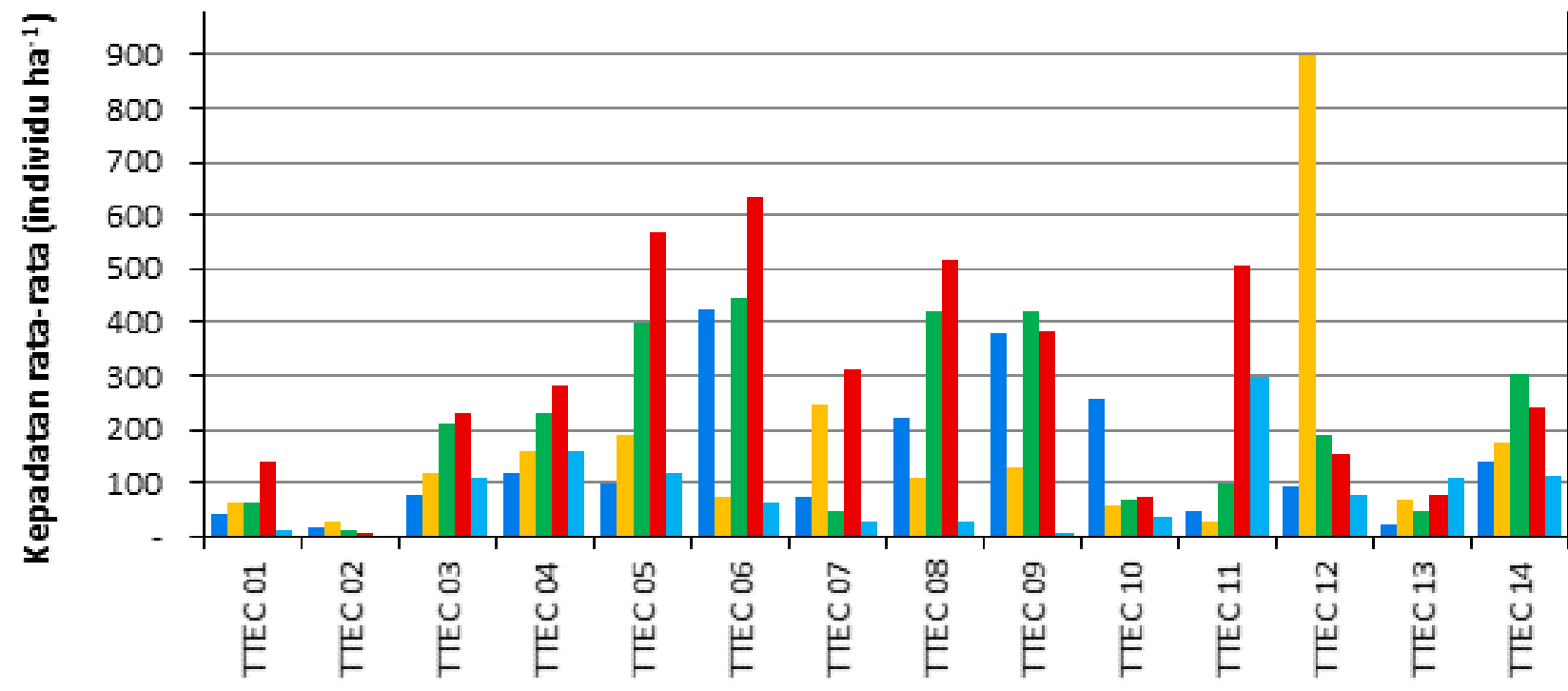

Stasiun Pengamatan

a $2012 \quad 2015 \quad 2016 \quad 2017 \quad 2018$

Gambar 12. Kepadatan megabentos di perairan Ternate dan sekitarnya pada masing-masing stasiun pengamatan pada tahun 2012-2018 
Data gabungan selama tahun 20122018, siput pemakan polip karang Drupella spp. memperlihatkan kepadatan tertinggi, 1.721 Ind/ha, yang diikuti bulu babi dengan kepadatan 443 Ind/ha. Selanjutnya, bintang laut biru Linckia laevigata memiliki kepadatan 125 Ind/ha, kerang kima 90 Ind/ha dan keong trokha 74 Ind/ha. Ketiga jenis atau kelompok jenis megabentos dengan kepadatan yang relatif rendah adalah teripang 36 Ind/ha, lobster 24 Ind/ha, dan bintang laut bermahkota duri Acanthaster planci dengan kepadatan 19 Ind/ha.

Kepadatan fauna bintang laut bermahkota duri Acanthaster planci berfluktuasi antara 5,1-56,1 Ind/ha pada tahun-tahun pengamatan. Uji statistik tidak menunjukkan perbedaan yang bermakna (Kruskal-Wallis, $\quad p=0,61>0,05$ ). Namun demikian, fluktuasi megabentos ini, terutama selama empat tahun terakhir, merupakan hal yang perlu dikhawatirkan. Alasan yang menjadi pertimbangan adalah: 1) Fluktuasi ketersebaran menunjukkan kecenderungan untuk meningkat (dari 1 stasiun pada tahun 2015 menjadi 5 stasiun pada tahun 2018); 2) Fluktuasi kepadatan menunjukkan kecenderungan meningkat (dari 5,1 Ind/ha pada tahun 2015 menjadi 56,1 Ind/ha pada tahun 2018); 3) Pengamatan terakhir (2018) memperlihatkan peningkatan kepadatan sebanyak $267 \%$ dari tahun sebelumnya; dan 4) Kepadatan 56,1 Ind/ha pada pengamatan tahun 2018 digolongkan pada kondisi outbreak (>15 Ind/ha) (Moran \& De'Ath, 1992; Bos et al., 2013).

Fluktuasi kepadatan lobster berkisar antara 10,2-51 Ind/ha, menunjukkan perubahan antar tahun yang tidak bermakna (Kruskal-Wallis, $p=0,65>0,05$ ). Fluktuasi kepadatan teripang berkisar antara 15,3 - 61,2 lnd/ha, menunjukkan perubahan antar tahun yang tidak bermakna (KruskalWallis, $p=0,61>0,05)$. Fluktuasi kepadatan kerang kima berkisar antara 71,4 - 122,4 Ind/ha, menunjukkan perubahan antar tahun tidak bermakna (Kruskal-Wallis, $p=0,69>0,05$ ). Fluktuasi kepadatan keong trokha berkisar antara 20,4 - 148 Ind/ha, menunjukkan perubahan antar tahun yang bermakna (Kruskal-Wallis, $\quad \mathrm{p}=0,01<0,05)$. Uji lanjut menunjukkan perbedaan yang bermakna bersumber pada perubahan kepadatan tahun 2017 dan 2018 kemudian 2012 dan 2017 (Nemenyi, $p=0,01<0,05)$. Fluktuasi kepadatan bintang laut biru Linckia laevigata berkisar antara 56,1-178,6 Ind/ha,

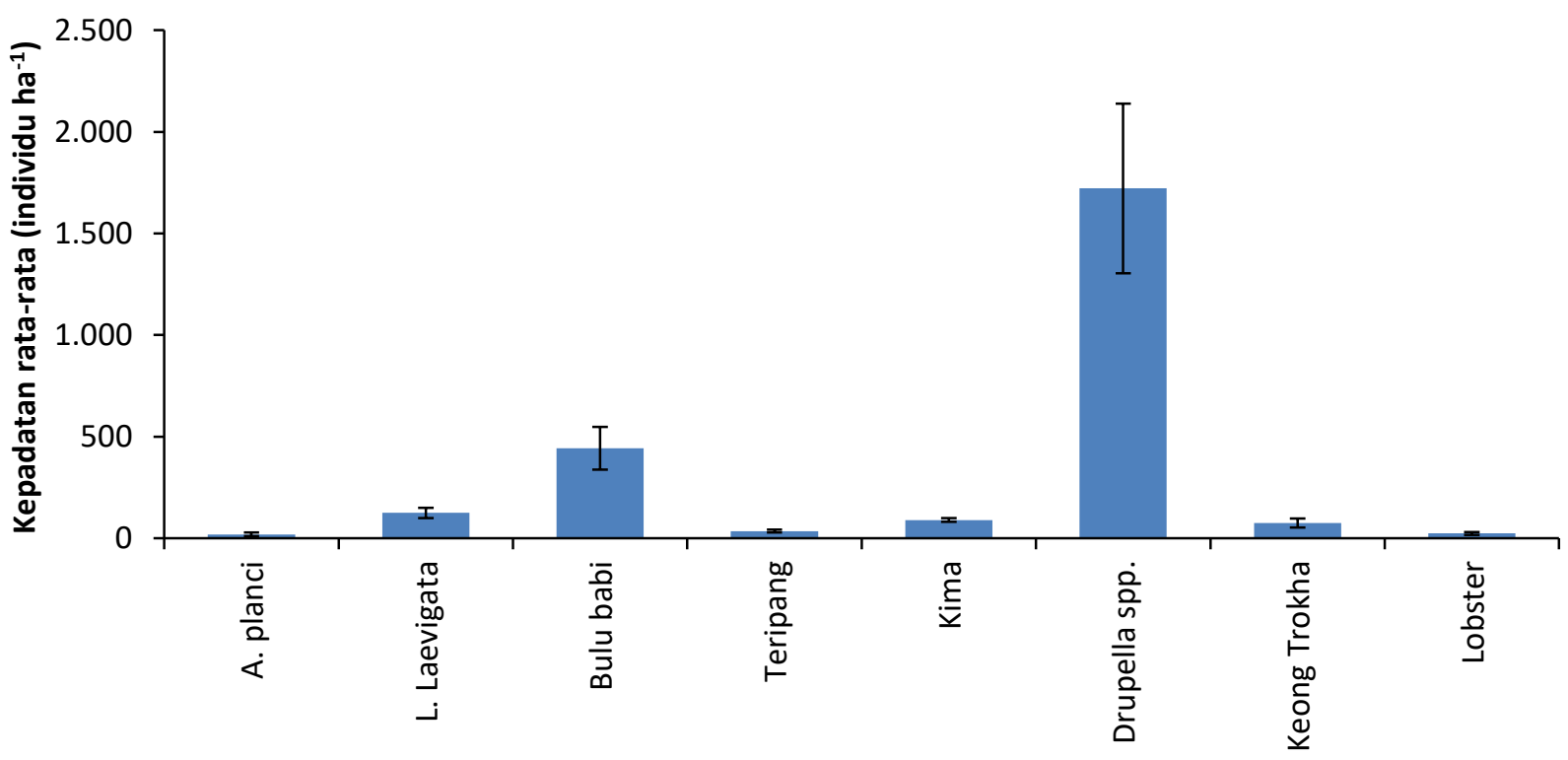

Jenis Megabentos

Gambar 13. Kepadatan rata-rata setiap jenis atau kelompok jenis megabentos di perairan Ternate dan sekitarnya pada tahun 2012-2018 


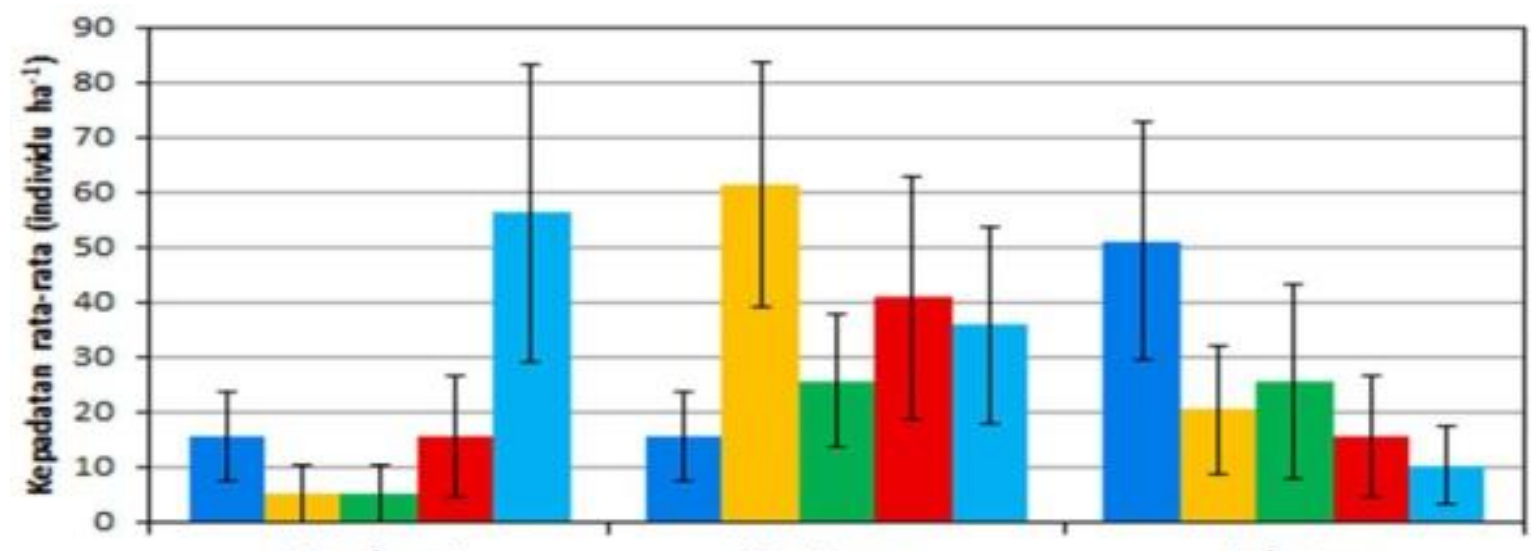

A. planci

Teripang

Lobster

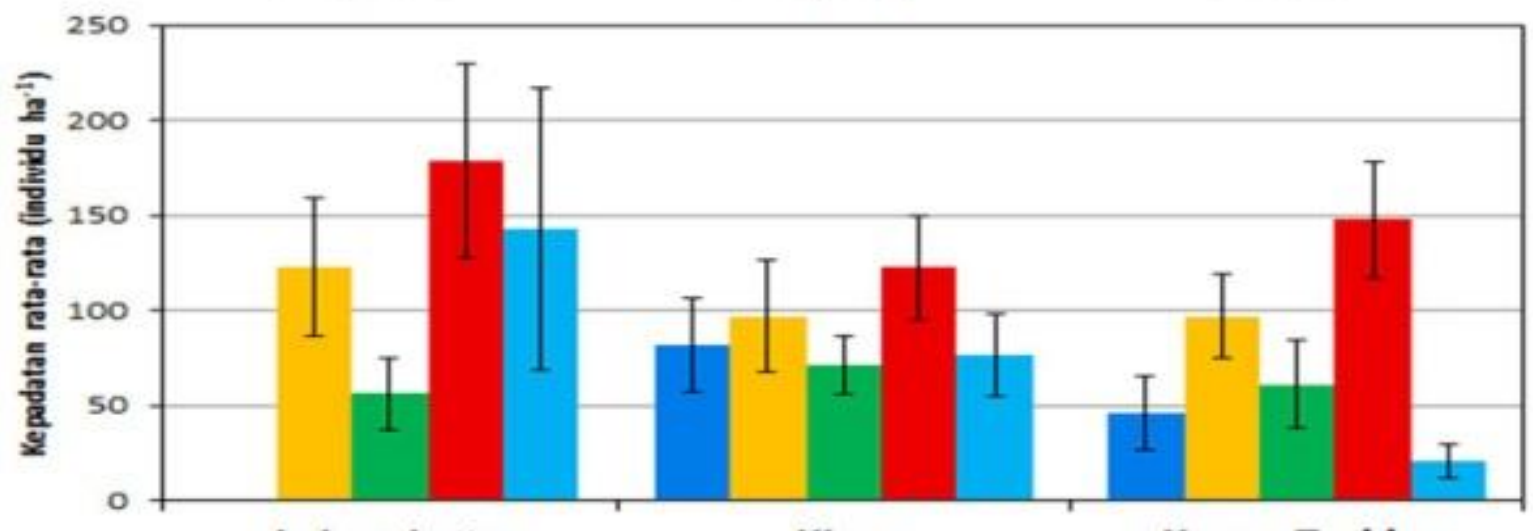

L. Laevigata

Kima

Keong Trokha

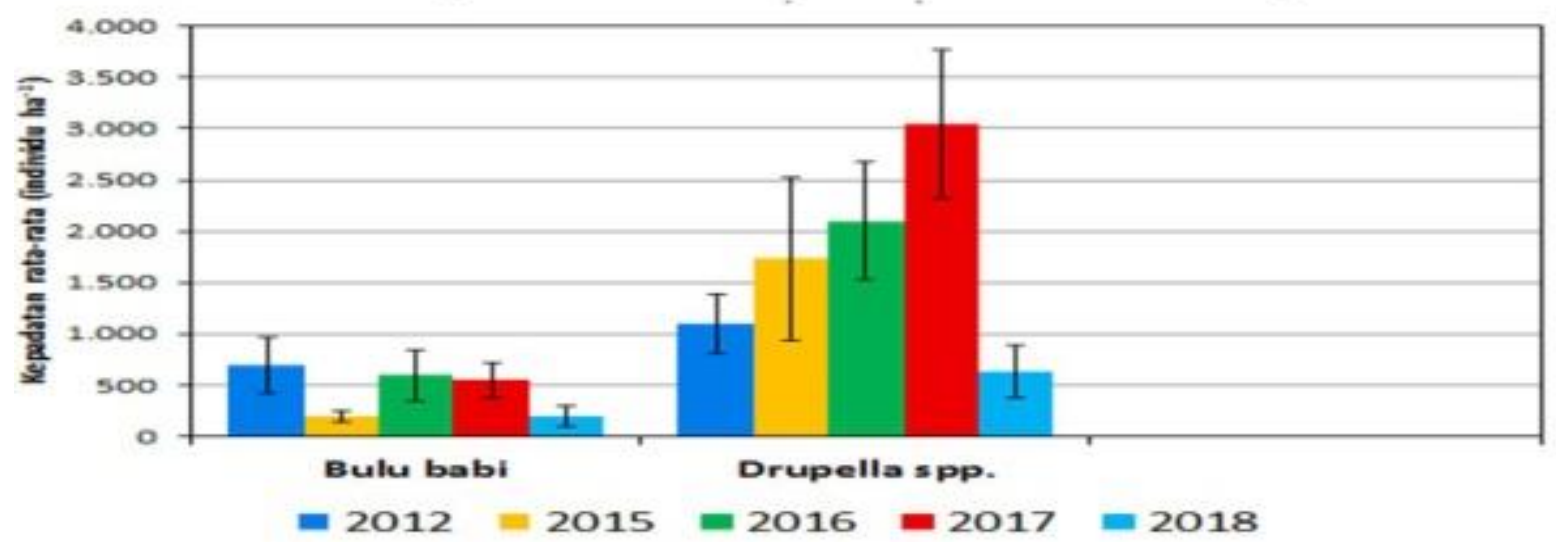

Gambar 14. Fluktuasi kepadatan setiap jenis atau kelompok jenis megabentos di perairan Ternate dan sekitarnya pada tahun 2012-2018

menunjukkan perubahan antar tahun tidak bermakna (Kruskal-Wallis, $\quad p=0,28>0,05$ ). Fluktuasi kepadatan bulu babi berkisar antara 188,8 - 693,9 Ind/ha, menunjukkan perubahan antar tahun yang tidak bermakna (Kruskal-Wallis, $p=0,28>0,05$ ). Fluktuasi kepadatan siput pemakan polip karang Drupella spp. berkisar antara 627,6 3.045,9 Ind/ha, menunjukkan adanya perubahan kepadatan yang bermakna (Kruskal-Wallis, $\quad \mathrm{p}=0,02 \quad<0,05$ ). Uji lanjut menunjukkan perbedaan tersebut bersumber pada perubahan kepadatan tahun 2017 dan 2018 (Nemenyi, $p=0,01<0,05$ ). Fluktuasi kepadatan megabentos tahun 2017-2018 disajikan pada Gambar 15.

Uji statistik dengan uji- $\dagger$ berpasangan memperlihatkan hasil yang serupa dengan ANOVA sebelumnya, yang memperlihatkan perubahan yang nyata pada kepadatan siput pemakan polip karang Drupella spp. 
dan keong trokha antara kedua tahun pengamatan. Uji ini juga menambahkan perubahan kepadatan yang nyata pada kepadatan bulu babi.

Keanekaragaman fauna megabentos di perairan Ternate dan sekitarnya pada tahun 2012- 2018 ini dikaji melalui beberapa indeks seperti indeks kekayaan jenis Margalef (lMarg), indeks dominansi Simpson (D), indeks keanekaragaman Shannon-Wiener $\left(H^{\prime}\right)$, dan indeks kemerataan Pielou (J') yang dapat dilihat pada Gambar16. Kondisi perairan umumnya diasumsikan baik dan stabil bila nilai indeks indeks kekayaan spesies tinggi, indeks dominansi rendah, indeks keanekaragaman tinggi dan indeks kemerataan tinggi. Interpretasi nilai indeksindeks ini perlu mengingat bahwa jenis-jenis yang diamati terbatasi pada delapan jenis atau kelompok jenis megabentos yang sebelumnya telah ditentukan (finite population).

Nilai cut-off 1 digunakan untuk indeks Dominansi dan Kemerataan adalah 0,5 (yang merupakan 50\% nilai maksimum 1,0), dan nilai cut-off 2 yang digunakan untuk indeks Keanekaragaman bernilai $1,04 \quad(50 \%$ nilai maksimum $\operatorname{Ln}(S)=2,08)$. Nilai indeks kekayaan spesies mengalami penurunan tahun 2012 hingga 2017, dari 1,17 menjadi 1,05.Namun kemudian nilai indeks tersebut mengalami peningkatan pada tahun 2018, menjadi 1,29, yang merupakan nilai indeks tertinggi selama kurun waktu 2012-2018. Peningkatan nilai ini menunjukkan peningkatan ketersebaran jenis megabentos yang diamati. Nilai indeks kemerataan $<0,5$ menunjukkan ada beberapa jenis fauna yang lebih dominan dibanding jenis yang lain. Dengan demikian, maka dapat dikatakan bahwa komunitas megabentos yang teramati pada tahun 2012 dan 2018 memiliki kemerataan fauna yang relatif merata, sedangkan komunitas yang teramati pada tahun 2015, 2016 dan 2017 memiliki kemerataan fauna yang relatif tidak merata. Nilai indeks dominansi menunjukkan kondisi dominansi pada komunitas megabentos yang ditentukan berdasarkan proporsi jumlah individu masing-masing jenis yang dijumpai di suatu lokasi yang sama. Bila proporsinya berimbang, nilai dominansi akan rendah, demikian pula sebaliknya. Nilai indeks ini berkisar dari 0-1 yang menyatakan dominansi rendah hingga tinggi. Dengan menggunakan nilai indeks dominansi 0,5 sebagai acuan adanya dominansi, maka dapat dikatakan bahwa dominansi yang relatif tinggi dijumpai pada komunitas megabentos yang teramati pada tahun 2015, 2016 dan 2017. Sedangkan komunitas megabentos yang diamati pada tahun 2012 dan 2018 memiliki dominansi yang relatif rendah.

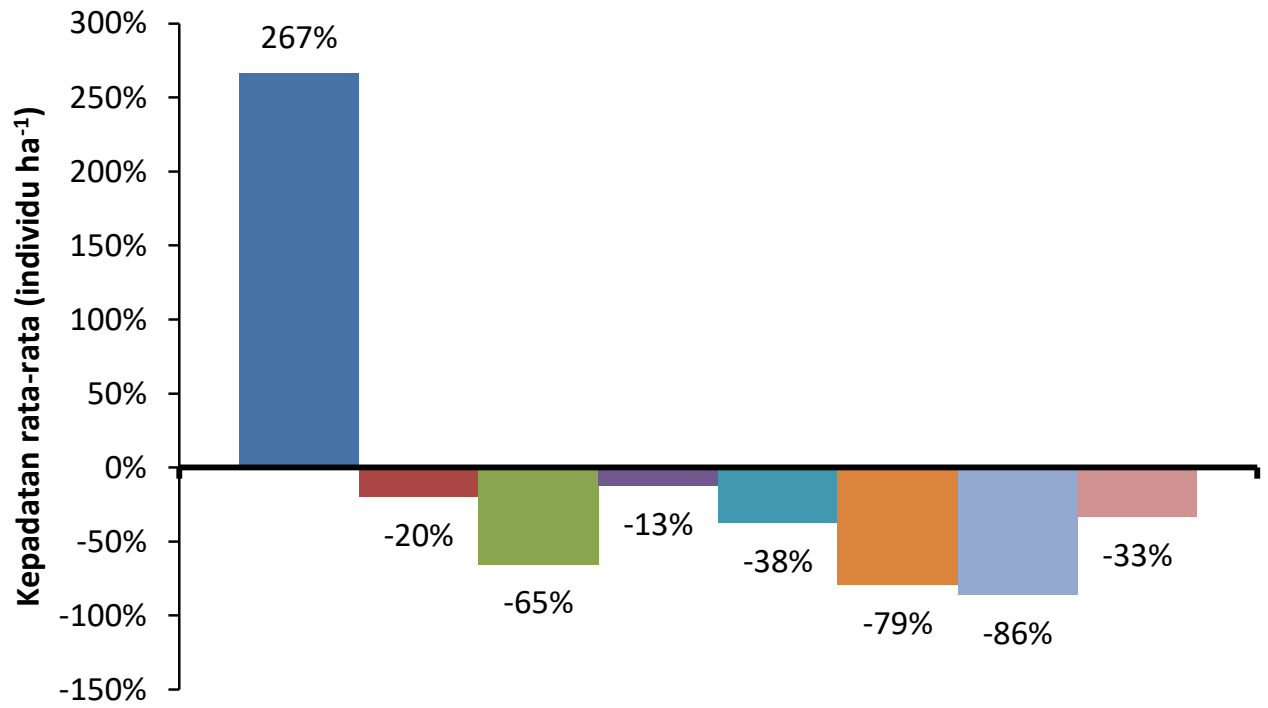

A. planci
L. Laevigata
Bulu babi
Teripang
Kima
Drupella spp.
Keong Trokha
Lobster

Jenis Megabentos

Gambar 15. Fluktuasi kepadatan megabentos di perairan Ternate dan sekitarnya pada tahun 2017 dan tahun 2018 


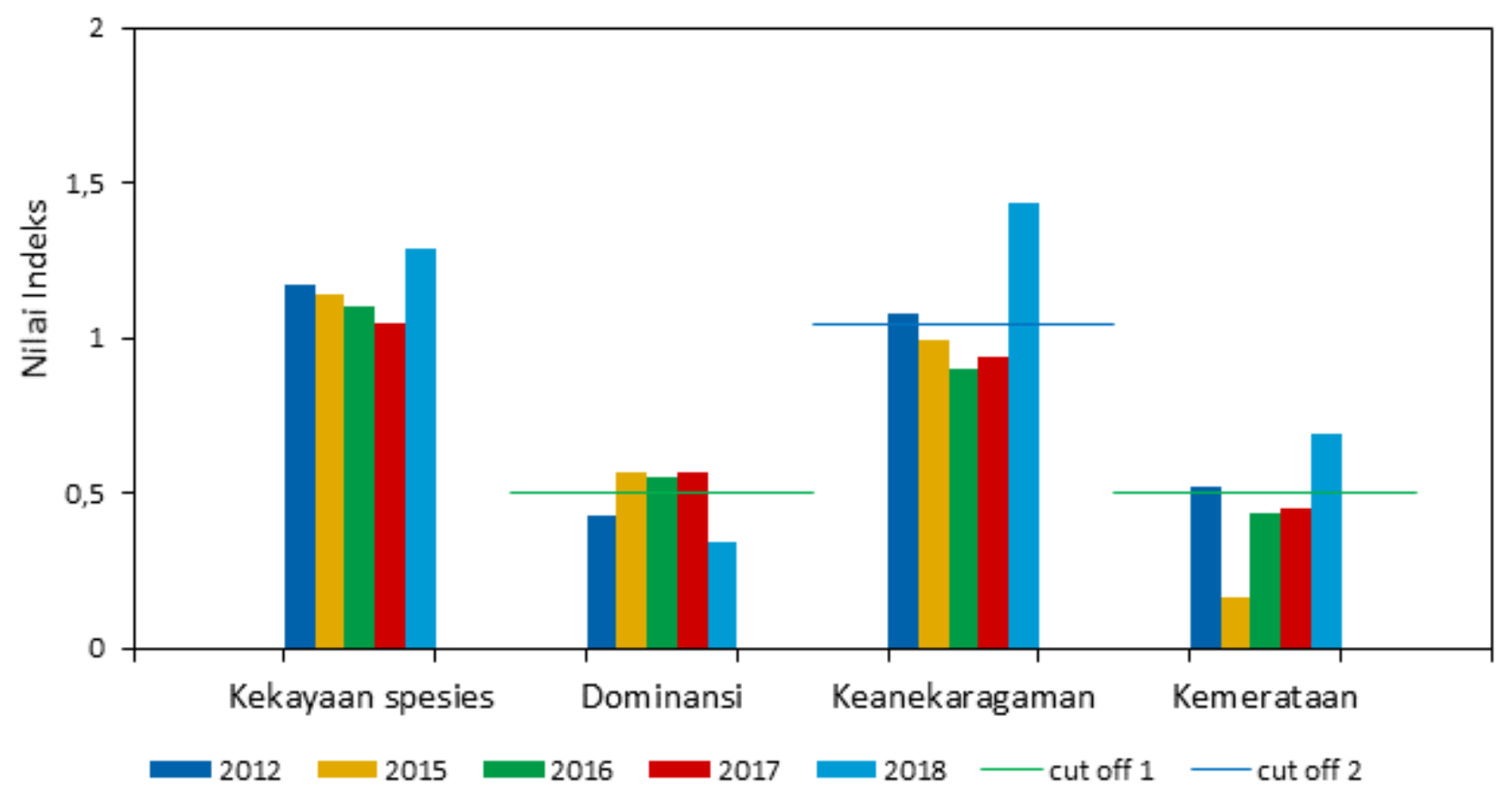

Gambar 16. Indeks ekologis megabentos tahun 2012-2018

Indeks keanekaragaman ( $H^{\prime}$ ) biasanya berbanding terbalik dengan dominansi. Makin tinggi dominansi makin rendah keanekaraman, dan demikian pula sebaliknya. Indeks ini bernilai dari 0,00-H'Max (yang merupakan Ln dari jumlah jenis maksimum, $\quad H^{\prime}{ }_{\text {Max }}=\quad$ 2,08).Dengan menggunakan asumsi bahwa indeks keanekaragaman yang lebih besar dari 50\% nilai tersebut (senilai 1,04) menunjukkan komunitas berkeanekaragaman relatif tinggi, maka dapat dikatakan bahwa komunitas megabentos yang teramati pada tahun 2012 dan 2018 memiliki keanekaragaman yang relatif tinggi, sedangkan komunitas yang teramati pada tahun 2015, 2016 dan 2017 berkeanekaragaman relatif rendah.

Indeks kemerataan Pielou (J') merupakan indeks yang menggambarkan kestabilan suatu komunitas perairan berdasarkan kemerataan jumlah individu jenis fauna yang hidup pada suatu lokasi. Suatu komunitas dikatakan stabil bila tersusun dari jenis-jenis dengan jumlah individu yang merata. Nilai indeks kemerataan jenis akan mendekati nilai 1 bila jumlah individu merata dan sebaliknya akan mendekati nilai 0 bila jumlah individu tidak merata. Karena penyebaran jumlah individu yang tidak merata juga mengindikasikan adanya dominasi oleh jenis tertentu, maka indeks kemerataan ini biasanya berbanding terbalik dengan indeks dominansi.

\section{KESIMPULAN}

Pengamatan megabentos pada tahun 2018 di perairan Ternate dan sekitarnya menunjukkan dominansi relatif rendah $(<0,5)$, keanekaragaman relatif tinggi (melebihi 50\% dari nilai maksimum) dan kehadiran jenis relatif cukup merata. Komunitas megabentos yang teramati tahun 2012 dan 2018 memiliki keanekaragaman relatif tinggi, sedangkan yang teramati tahun 2015, 2016 dan 2017 memiliki keanekaragaman relatif rendah. Komunitas megabentos yang teramati tahun 2012 dan 2018 memiliki kemerataan relatif merata, sedangkan yang teramati tahun 2015, 2016 dan 2017 memiliki kemerataan relatif tidak merata.Dominansi yang relatif tinggi dijumpai pada pengamatan tahun 2015, 2016 dan 2017, sedangkan komunitas megabentos yang diamati tahun 2012 dan 2018 memiliki dominansi relatif rendah. Drupella spp. merupakan kelompok jenis megabentos yang paling dominan dan memiliki ketersebaran paling merata. Fluktuasi Acanthaster planci selama empat tahun terakhir memiliki ketersebaran dan kepadatan cenderung meningkat 


\section{UCAPAN TERIMA KASIH}

Penulis menyampaikan terima kasih kepada Pusat Penelitian Oseanografi Lembaga IImu Pengetahuan Indonesia (P2O - LIPI) atas pendanaan pemantavan dan penelitian ini di bawah skema Reef Health Monitoring P2O - LIPI Program COREMAP-CTI Tahun Anggaran 2012, 2015, 2016, 2017 dan 2018.

\section{DAFTAR PUSTAKA}

Abbott, R.T. \& Dance, P. 1990. Compendium of Seashell. Crawford. House Press, Australia: 411 pp.

Arbi, U.Y \& Sihaloho, H.F. 2017. Panduan Pemantauan Megabentos, edisi 2. COREMAP-CTI LIPI, Jakarta: 45 pp.

Bos, A.R., Gumanao, G.S., Mueller, B. \& Saceda-Cardoza, M.M.E. 2013. Management of crown-of-thorns sea star (Acanthaster planci L.) outbreaks: Removal success depends on reef topography and timing within the reproduction cycle. Ocean \& Coastal Management 71:116-122.

Brander, L.M., van Beukering, P. \& Cesar, H.S. 2007. The recreational value of coral reefs: a meta-analysis. Ecological Economics 63(1):209-218.

Clark, A.M. \& Rowe, F.E.W. 1971. Monograph of Shallow Water Indo-West Pacific Echinoderms. British Museum (Natural History), London: 238 pp.

Colin, P.L. \& Arneson, C. 1995. Tropical Pacific Invertebrates. Coral Reef Press. California: $341 \mathrm{pp}$.

Entrambasaguas, L., Pérez-Ruzafa, Á., GarcíaCharton, J.A., Stobart, B. \& Bacallado, J.J. 2008. Abundance, spatial distribution and habitat relationships of echinoderms in the Cabo Verde Archipelago (eastern
Atlantic). Marine and Freshwater Research 59(6): 477.

Giyanto, Mumby, P., Sjafrie N.D.M., Abrar, M. \& Iswari, M.Y. 2017. Indeks Kesehatan Terumbu Karang. COREMAP-CTI, Jakarta: $99 \mathrm{pp}$.

Loya, Y. 1978. Plotless and Transect Methods, in: Stoddard, D.R., and R.E. Johannes, Coral Reef Research Methods, Paris (UNESCO): 22-32.

Matsura, K., Sumadiharga, O.K. \& Tsukamoto, K. 2000. Field Guide to Lombok Island.Identification Guide to Marine Organism in Seagrass Beds of Lombok Island, Indonesia. University of Tokyo: 449 $\mathrm{pp}$.

McCook, L.J., Ayling, T., Cappo, M., Choat, J.H., Evans, R.D., De Freitas, D.M. \& Mapstone, B. 2010. Adaptive management of the Great Barrier Reef: a globally significant demonstration of the benefits of networks of marine reserves. Proceedings of the National Academy of Sciences, 107(43): 18278-18285.

Moberg, F. \& Folke, C. 1999. Ecological goods and services of coral reef ecosystems. Ecological Economics 29(2): 215-233.

Moran, P.J. \& De'Ath, G. 1992. Estimates of the abundance of the crown-of-thorns starfish Acanthaster planci in outbreaking and non-outbreaking populations on reefs within the Great Barrier Reef. Marine Biology 113:509-515.

Neira, R.O. \& Cantera, J.R.K. 2005. Composición Taxonómica y Distribución de las Asociaciones de Equinodermos en los Ecosistemas Litorales del Pacifico Colombiano. Revista de Biología Tropical. 53 (3): 195-206.

Yusron, E. 2006. Biodiversitas Ekhinodermata di perairan Pantai Takofi, Pulau Moti Maluku Utara. Makara Sains 10(1): 41-46 